\title{
Sustainable Solution for Construction Industry by Using Fly Ash
}

\author{
Sudipta Adhikary ${ }^{1}$, Bulbul Debnath ${ }^{2}$, Saswata Chattopadhyay ${ }^{3}$ \\ ${ }^{1}$ Lecturer in Civil Engineering Department, Camellia School of Engineering \& Technology, Barast, Nadibhag. \\ ${ }^{2 \& 3}$ Student of $3^{r d}$ Year Civil Engineering Department, Camellia School of Engineering \& Technology, Barast, \\ Nadibhag
}

\begin{abstract}
Fly ash is a fine grey powder consisting of spherical particles that are produced as a by-product in coal fired power station. It has been generally used for land filling. In recent times, the importance and use of fly ash has grown so much that it has almost become a common ingredient of concrete particularly making in high strength and high performance concrete. The use of fly ash as concrete admixtures not only extends technical advantage but also contributes to the environmental pollution control. Extensive research is being carried out in most part of the world that could be occurred in the utilization of Fly ash, which is basically a waste product.
\end{abstract}

The present study mainly concentrate on the various kind of application of fly ash, specially in the civil engineering field and also on it's significant properties.

Key words: NAA, POZZOLANIC, CEMENTITIOUS,

\section{Introduction:}

Fly ash generated by burning coal in coal fired power station, was considered still a few years back as mere waste material. This was considered as a material of very low value, probably no use except land filling. But in the year of 1967 in Pittsburgh, John H. Faber, the first executive director of National Ash Association(NAA), was making a successful plan to use fly ash in many sector of civil engineering field and other also. Due to mainly his efforts, the NAA was formed in 1968 and became recognized as the world's leading authority in coal ash technology and utilization.

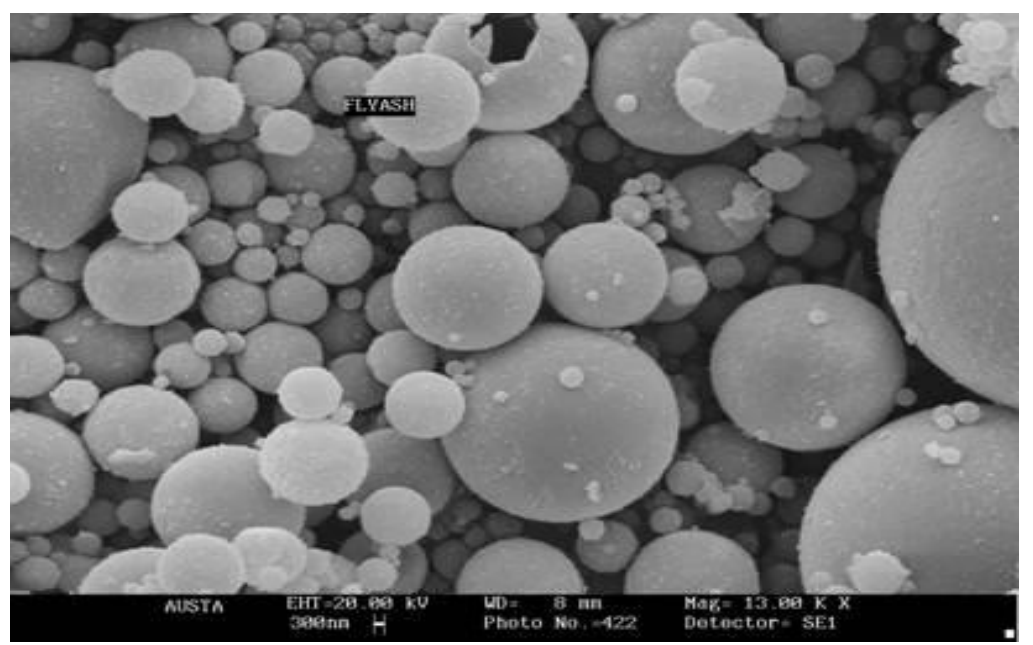

[Moleculer image of FLY ASH]

Due to increased use of pulverised coal in the electric power generation plants, fly ash is now available in most areas of the U.S.A , Canada, Europe , China and many other countries of the world. Approximately 37 million tonnes of fly ash was produced annually by the year $1989-90$ and now, it is growing constantly. About mere 3\% of total fly ash production is used in India, which is a liabilities explore our lack of practical application awareness about the versatile application of the material itself.

TYPES OF "FLY ASH" AS PER ASTM:

ASTM broadly classify fly ash into two classes:

D Class F: Fly ash normally produced by burning anthracite or bituminous coal, usually has less than $5 \% \mathrm{CaO}$. Class $\mathrm{F}$ fly ash has pozzolanic properties only. 
Class C: Fly ash normally produced by burning lignite or sub-bituminous coal. Some class C fly ash may have $\mathrm{CaO}$ content in excess of $10 \%$. In addition to pozzolanic properties, class $\mathrm{C}$ fly ash also possesses cementitious properties.

CHEMICAL COMPOSITION OF FLY ASH:

Main chemical properties of "Fly Ash" is represented by the following table :

\begin{tabular}{|c|l|c|}
\hline Serial no & \multicolumn{1}{|c|}{ Constituent } & Percentage \\
\hline 1 & $\mathrm{SiO}_{2}+\mathrm{Al}_{2} \mathrm{O}_{3}+\mathrm{Fe}_{2} \mathrm{O}_{3}$ & 94.25 \\
\hline 2 & Sulphur tri oxide $\left(\mathrm{sO}_{3}\right)$ & 0.71 \\
\hline 3 & Sodium oxide $\left(\mathrm{Na}_{2} \mathrm{O}\right)$ & 0.26 \\
\hline 4 & Loss on ignition & 0.38 \\
\hline 5 & Silica $\left(\mathrm{sio}_{2}\right)$ & 59.90 \\
\hline 6 & Alumina $\left(\mathrm{Al}_{2} \mathrm{O}_{3}\right)$ & 30.81 \\
\hline 7 & Iron $\left(\mathrm{Fe}_{2} \mathrm{O}_{3}\right)$ & 3.83 \\
\hline 8 & Reactive $\left(\mathrm{SiO}_{2}\right)$ & 30.01 \\
\hline 9 & Calcium oxide $(\mathrm{Cao})$ & 1.94 \\
\hline 10 & Free Calcium oxide $(\mathrm{cao})$ & $\mathrm{Nil}$ \\
\hline 11 & Reactive $(\mathrm{cao})$ & 1.44 \\
\hline 12 & Chloride $(\mathrm{Cl})$ & 0.009 \\
\hline 13 & Magnesium oxide $(\mathrm{Mgo})$ & 0.36 \\
\hline 14 & Manganese di oxide $\left.(\mathrm{MnO})_{2}\right) \mathrm{mg} / \mathrm{kg}$ & 12.38 \\
\hline 15 & Potassium oxide $\left(\mathrm{K}_{2} \mathrm{Op}_{2} \mathrm{O}_{5}\right) \mathrm{mg} / \mathrm{kg}$ & 0.031 \\
\hline
\end{tabular}

Comparison Of Chemical Composition Depending On Class Of Fly Ash:

\begin{tabular}{|l|l|l|l|}
\hline table 1 & \multicolumn{3}{|l|}{} \\
\hline ingredients (wt.\%) & lignite fly ash A & lignite fly ash B & class C fly ash \\
\hline $\mathrm{SiO}_{2}$ & 24 & 21 & 65 \\
\hline $\mathrm{Fe}_{2} \mathrm{O}_{3}$ & 10 & 9 & 10 \\
\hline $\mathrm{CaO}^{1}$ & 41 & 42 & 11 \\
\hline $\mathrm{MgO}$ & 4 & 8 & 3 \\
\hline $\mathrm{Al}_{2} \mathrm{O}_{3}$ & 11 & 5 & 9 \\
\hline $\mathrm{SiO}_{2}+\mathrm{Fe}_{2} \mathrm{O}_{3}+\mathrm{Al}_{2} \mathrm{O}_{3}$ & 45 & 35 & 84 \\
\hline $\mathrm{Na}_{2} \mathrm{O}$ & 0 & 5 & 0 \\
\hline $\mathrm{K}_{2} \mathrm{O}$ & 0 & 1 & 1 \\
\hline $\mathrm{SO}_{3}$ & 10 & 9 & 1 \\
\hline & & & \\
\hline $\mathrm{Free} \mathrm{lime}^{1}$ & 8 & 12 & 0 \\
\hline \multicolumn{5}{|l}{} \\
\hline
\end{tabular}

PHYSICAL PROPERTIES OF FLY ASH :

Main physical properties of "Fly Ash" is represented by the following table :

\begin{tabular}{|c|c|c|}
\hline Serial no & Physical parameters & Values \\
\hline 1 & Fineness residue retains on $325 \mu$ sieve $(\%)$ & 9.02 \\
\hline 2 & Moisture content $(\%)$ & 0.080 \\
\hline 3 & Comparative compressive strength at 28 days with OPC (\%) & 91.90 \\
\hline 4 & Initial setting time(OPC/Pfa)minutes & $150 / 170$ \\
\hline 5 & Soundness by Le chateliers expansion(mm) & 0.70 \\
\hline 6 & Particle density(kg/cum) & 2150 \\
\hline
\end{tabular}

\section{ENGINEERING PROPERTIES OF FLY ASH:}

Some of the engineering properties of fly ash that are of particular interest when fly ash is used as an admixture or a cement addition to PCC mixes include fineness, LOI, chemical composition, moisture content, and pozzolanic activity. Most specifying agencies refer to ASTM C618 when citing acceptance criteria for the use of fly ash in concrete.

\section{FINENESS:}

Fineness is the primary physical characteristic of fly ash that relates to pozzolanic activity. As the fineness increases, the pozzolanic activity can be expected to increase. Current specifications include a requirement for the maximum allowable percentage retained on a $0.045 \mathrm{~mm}$ (No. 325) sieve when wet sieved. ASTM C618 specifies a maximum of 34 percent retained on a $0.045 \mathrm{~mm}$ (No. 325) sieve. Fineness can also be 
assessed by methods that estimate specific surface area, such as the Blaine air permeability test commonly used for Portland cement.

POZZOLANIC ACTIVITY: (Chemical Composition and Mineralogy): Pozzolanic activity refers to the ability of the silica and alumina components of fly ash to react with available calcium and/or magnesium from the hydration products of Portland cement. ASTM C618 requires that the pozzolanic activity index with Portland cement, as determined in accordance with ASTM C311 be a minimum of 75 percent of the average 28-day compressive strength of control mixes made with Portland cement.

LOSS OF IGNITION: Many state transportation departments specify a maximum LOI value that does not exceed 3 or 4 percent, even though the ASTM criteria is a maximum LOI content of 6 percent. This is because carbon contents (reflected by LOI) higher than 3 to 4 percent have an adverse effect on air entrainment.

Fly ashes must have a low enough LOI (usually less than 3.0 percent) to satisfy ready-mix concrete producers, who are concerned about product quality and the control of air-entraining admixtures. Furthermore, consistent LOI values are almost as important as low LOI values to ready-mix producers, who are most concerned with consistent and predictable quality.

\section{MOISTURE CONTENT:}

ASTM C618 specifies a maximum allowable moisture content of 3.0 percent.

Some of the properties of fly ash-concrete mixes that are of particular interest include mix workability, time of setting, bleeding, pumpability, strength development, heat of hydration, permeability, resistance to freeze-thaw, sulfate resistance, and alkali-silica reactivity.

\section{WORKABILITY:}

At a given water-cement ratio, the spherical shape of most fly ash particles permits greater workability than with conventional concrete mixes. When fly ash is used, the absolute volume of cement plus fly ash usually exceeds that of cement in conventional concrete mixes. The increased ratio of solids volume to water volume produces a paste with improved plasticity and more cohesiveness.

\section{TIMES OF SETTING:}

When replacing up to 25 percent of the Portland cement in concrete, all Class F fly ashes and most Class C fly ashes increase the time of setting. However, some Class C fly ashes may have little effect on, or possibly even decrease, the time of setting. Delays in setting time will probably be more pronounced, compared with conventional concrete mixes, during the cooler or colder months.

\section{BLEEDING}

Bleeding is usually reduced because of the greater volume of fines and lower required water content for a given degree of workability.

\section{PUMPABILITY:}

Pumpability is increased by the same characteristics affecting workability, specifically, the lubricating effect of the spherical fly ash particles and the increased ratio of solids to liquid that makes the concrete less prone to segregation.

\section{STRENGTH DEVELOPMENT:}

Previous studies of fly ash concrete mixes have generally confirmed that most mixes that contain Class F fly ash that replaces Portland cement at a 1:1 (equal weight) ratio gain compressive strength, as well as tensile strength, more slowly than conventional concrete mixes for up to as long as 60 to 90 days. Beyond 60 to 90 days, Class F fly ash concrete mixes will ultimately exceed the strength of conventional PCC mixes. For mixes with replacement ratios from 1.1 to $1.5: 1$ by weight of Class F fly ash to the Portland cement that is being replaced, 28-day strength development is approximately equal to that of conventional concrete.

Class C fly ashes often exhibit a higher rate of reaction at early ages than Class F fly ashes. Some Class C fly ashes are as effective as Portland cement in developing 28-day strength. Both Class F and Class C fly ashes are beneficial in the production of high-strength concrete. However, the American Concrete Institute (ACI) recommends that Class F fly ash replace from 15 to 25 percent of the Portland cement and Class C fly ash replace from 20 to 35 percent. 


\title{
HEAT OF HYDRATION:
}

The initial impetus for using fly ash in concrete stemmed from the fact that the more slowly reacting fly ash generates less heat per unit of time than the hydration of the faster reacting Portland cement. Thus, the temperature rise in large masses of concrete (such as dams) can be significantly reduced if fly ash is substituted for cement, since more of the heat can be dissipated as it develops. Not only is the risk of thermal cracking reduced, but greater ultimate strength is attained in concrete with fly ash because of the pozzolanic reaction. Class F fly ashes are generally more effective than Class $\mathrm{C}$ fly ashes in reducing the heat of hydration.

\section{PERMEABILITY:}

Fly ash reacting with available lime and alkalies generates additional cementitious compounds that act to block bleed channels, filling pore space and reducing the permeability of the hardened concrete. The pozzolanic reaction consumes calcium hydroxide $\left(\mathrm{Ca}(\mathrm{OH})_{2}\right)$, which is leachable, replacing it with insoluble calcium silicate hydrates $(\mathrm{CSH})$. The increased volume of fines and reduced water content also play a role.

\section{RESISTANCE TO FREEZE-THAW:}

As with all concretes, the resistance of fly ash concrete to damage from freezing and thawing depends on the adequacy of the air void system, as well as other factors, such as strength development, climate, and the use of deicer salts. Special attention must be given to attaining the proper amount of entrained air and air void distribution. Once fly ash concrete has developed adequate strength, no significant differences in concrete durability have usually been observed. There should be no more tendency for fly ash concrete to scale in freezing and thawing exposures than conventional concrete, provided the fly ash concrete has achieved its design strength and has the proper air void system.

\section{SURFACE RESISTANCE:}

Class F fly ash will generally improve the sulfate resistance of any concrete mixture in which it is included. Some Class C fly ashes may improve sulfate resistance, while others may actually reduce sulfate resistance and accelerate deterioration. Class $\mathrm{C}$ fly ashes should be individually tested before use in a sulfate environment. The relative resistance of fly ash to sulfate deterioration is reportedly a function of the ratio of calcium oxide to iron oxide.

\section{ALKALI-SILICA REACTIVITY:}

Class $\mathrm{F}$ fly ash has been effective in inhibiting or reducing expansive reactions resulting from the alkali-silica reaction. In theory, the reaction between the very small particles of amorphous silica glass in the fly ash and the alkalis in the Portland cement, as well as the fly ash, ties up the alkalis in a nonexpansive calciumalkali-silica gel, preventing them from reacting with silica in aggregates, which can result in expansive reactions. However, because some fly ashes (including some

Class C fly ashes) may have appreciable amounts of soluble alkalis, it is necessary to test materials to be used in the field to ensure that expansion due to alkali-silica reactivity will be reduced to safe levels.

Fly ash, especially Class F fly ash, is effective in three ways in substantially reducing alkali-silica expansion:

1) It produces a denser, less permeable concrete;

2) When used as a cement replacement it reduces total alkali content by reducing the Portland cement; and

3) Alkalis react with fly ash instead of reactive silica aggregates.

Class F fly ashes are probably more effective than Class $\mathrm{C}$ fly ashes because of their higher silica content, which can react with alkalis. Users of Class $C$ fly ash are cautioned to carefully evaluate the long-term volume stability of concrete mixes in the laboratory prior to field use, with ASTM C441 as a suggested method of test

\section{UTILIZATION OF FLY ASH:}

Keeping in view this versatility of fly ash, several agencies - (govt. private, public sector, NGOs) are involved in fly ash utilization and safe disposal efforts in India. These include Ministry of Environment \& forests, Ministry of Urban Development, Department of Science \& Technology, National Thermal Power Corporation, CSIR Laboratories, Engineering Institutes, IITs, State Electricity Boards, etc.

\author{
Areas of Fly Ash Utilization \\ Fly Ash Bricks \\ Embankment and Fills \\ Road Pavement \\ Portland Pozzolona Cement \\ Cement Concrete and Mortar \\ Light Weight Aggregates
}


Back filling of Open Cast Mine

Stowing of Under Ground Mines

Agriculture

Manufacture of Alum, Paint, Ceramic, Asbestos Cement Products.

MODE OF FLY ASH UTILIZATION DURING 2010-11

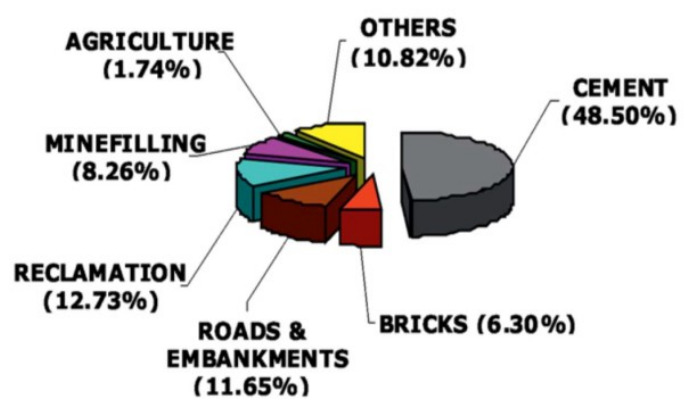

CASES WHERE FLY ASH HAS BEEN USED IN INDIA:

Fly ash utilization in Mass concrete or Dam construction

\begin{tabular}{|l|l|l|l|l|}
\hline Sl. No & Structures & State & Cement replaced (\%) & Source of fly ash \\
\hline 1. & Gurgoan tunnel & Haryana & 15 & Delhi \\
\hline 2. & Jawar sagar Dam & Rajasthan & 20 & Delhi \\
\hline 3. & Kakki Dam & Kerala & 20 & Neyveli \\
\hline 4. & Navora barrage & U.P. & 15 & Harduaganj \\
\hline 5. & Rihad Dam & U.P. & 15 & Bokaro \\
\hline 6. & Sone Barrage & Bihar & 15 & Bokaro \\
\hline 7. & Umium Project & Assam & Not available & Durgapur \\
\hline 8. & Chandil dam & Bihar & 25 & Talcher \\
\hline
\end{tabular}

Table: Fly ash Experimental Housing Schemes By National Buildings Organisation

\begin{tabular}{|l|l|}
\hline Location & Application \\
\hline Hindustan Prefab Ltd. Staff Quarters, New Delhi & $15 \%$ replacement of fly ash in precast RCC components. \\
\hline Government double storied staff quarters R.K.Puram at New Delhi & $20 \%$ fly ash in cement and mortar \\
\hline 4 storied Government quarters at dhaulakuan New Delhi & $20 \%$ fly ash in cement and mortar \\
\hline Double storied building at the S.E.R.C.Chennai. & Precast reinforced channel units \\
\hline Dwelling units at Pankha road, New Delhi & Foundation, Concrete mortar flooring plaster some RCC items \\
\hline Flats at Besant Nagar, Chennai & Cement mixture \\
\hline
\end{tabular}

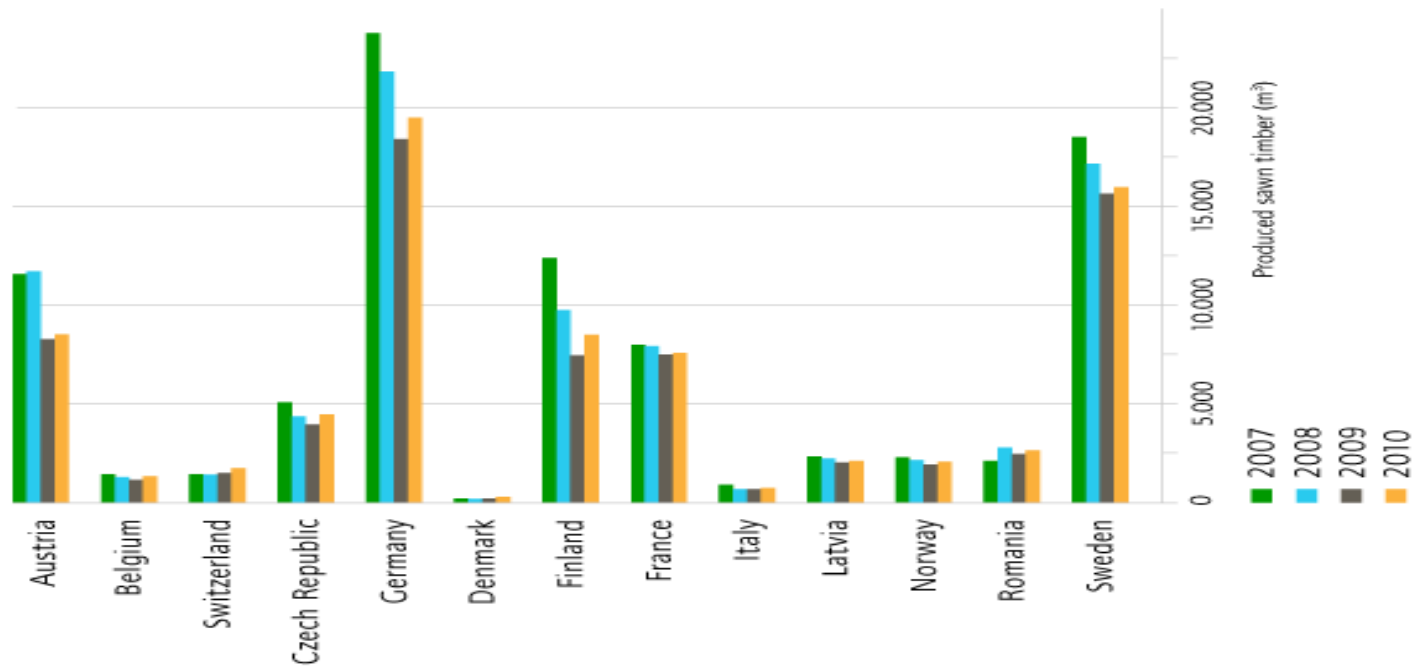

FLY ASH UTILIZATION APART FROM INDIA: 


\section{BENEFITS OF USING FLY ASH:}

- GREATER STRENGTH: Fly ash increases in strength over time, continuing to combine with free lime.

- DECREASED PERMEABILITY: Increased density and long-term pozzolanic action of fly ash, which ties up free lime, results in fewer bleed channels and decreases permeability.

- INCREASED DURABILITY. The lower permeability of concrete with fly ash also helps keep aggressive compounds on the surface, where destructive action is lessened. Fly ash concrete is also more resistant to attack by sulphate, mild acid, and soft (lime hungry) water.

- REDUCED ALKALI SILICA REACTIVITY: Fly ash combines with alkalis from cement that might otherwise combine with silica from aggregates, thereby preventing destructive expansion.

- REDUCED HEAT OF HYDRATION: The pozzolanic reaction between fly ash and lime generates less heat, resulting in reduced thermal cracking when fly ash is used to replace a percentage of Portland Cement.

- REDUCED EFFLORESCENCE: Fly ash chemically binds free lime and salts that can create efflorescence. The lower permeability of concrete with fly ash can help to hold efflorescence-producing compounds inside the concrete.

The ball-bearing effect of fly ash in concrete creates a lubricating action when concrete is in its plastic state. This means ENHANCED CONCRETE WORKABILITY.

\section{SCOPE OF THE STUDY OF FLY ASH CHARACTERISTICS:}

The importance of fly ash cannot be exaggerated. It is no longer a cheap substitute of cement, nor an extender or addition to the mix,Fly ash bestows important advantages upon concrete, and its therefore, essential to understand The role and influence of fly ash. The variability of fly ash arises from the fact that fly ash is not a specially manufactured product and cannot, therefore be governed by strict requirements of standard . The power station which produces fly ash varies its operation in response to the power demand. The variation in the fly ash are those in glass content, carbon content, particle shape and size distribution, as well as in the presence of magnesia and other minerals, and even in colour. It is possible to improve the size distribution of fly ash particles by classification and by grinding.

As said earlier the fly ash is an artificial pozzolan and it exhibits different characteristics with different compounds of cement. The cement might contain different compositions of the above said Tri calcium silicate, Di calcium silicate, tri calcium aluminate etc. hence it becomes necessary to study the reactions exhibited by the fly ash with each of these compounds so that the necessary concrete can be obtained. Hence the cement should match with the fly ash at the first instance. This becomes important because it might have an affect on the strength and durability of the concrete.

\section{References:}

[1] Faber, J. H. 40 Years of Ash Marketing in the U.S.A. In Proceedings of the Utilization of Ash Workshop, May 13-15, 1987. University of North Dakota, Grand Forks, ND; pp I-1-I-7.

[2] hanumatidas N. and Kalidas N.; Portland pozolana cement : An extravagant ignorance.International conference of fly ash Disposal and utilisation Central Borad of Irrigation and Power.

[3] Raghavendra N.; Portland pozzolana cement; Quality, performance and Durability.

[4] Ranga Rao V., Ddoctoral thesis submitted to Andhra University, 1998

[5] file:///F:/fly \%20ash/Civil $\% 20$ Engineering $\% 20 \% 20 \mathrm{FLY} \% 20 \mathrm{ASH} . \mathrm{htm}$.

[6] Baykal, G. and Doven, A. G, (2000), Resources, Conservation \& Recycling 30 59-77.

[7] Halstead, W. J. (October 1986), Use of fly ash in concrete. NCHRP 127, Washington:

[8] Transportation Research Board, National Research Council. Ministry of Finance, (2000), 8th Malaysian Plan, Chapter 11, 337.

[9] Swamy, R. N and Lambert, G. H, (1981), 'The Microstructure of Lytag Aggregate' The International Journal of Cement Composite and LightweightConcrete, Volume 3, No.

[10] jp.europeanwood.org.

[11] Journal : 2005 World of Coal Ash (WOCA), April 11-15, 2005, Lexington, Kentucky, USA

[12] Journal : IJIRSET, Vol-3, issue May 5, 2014.

[13] Fly Ash Utilisation for Value added products, Eds: B.chatterjee, K.K. singh \& N.G. Goswami (c) 1999, NML, Jamshedpur, pp. 6973

[14] Journal of Nuclear and Related Technology Vol. 4, Special Edition 2007, 47-51. 